\title{
Alegorické a reálné v románu a filmu
}

\section{Cesta}

\author{
Petr Bubeníček
}

\begin{abstract}
The Allegorical and the Real in the Novel and the Film The Road

The study is concerned with The Road, a post-apocalyptic novel by Cormac McCarthy, and with its film adaptation. It follows the artistic configurations involved, as they reduce people to their biological foundations while, at the same time, pointing to the survival of rudimentary ethical consciousness even in individuals living in extremely strained conditions. The film, especially, shows the downfall of the protagonist into post-apocalyptic horror as leading to the eventual discovery of his quintessential humanity. Moreover, the text by McCarthy can also be read as a postmodern argument against the rationale of modernism: instrumental behaviours stand opposed to ethical behaviour, which is irrational in that it disadvantages those who engage in it. The study examines why, in $\mathrm{McCarthy}$, this divine, ethical principle does not go the way of the rest of the bygone symbolic system, i.e. devolves into a mere phantasma.
\end{abstract}

\section{KEYWORDS}

Novel, film, adaptation, the event (Derrida), the real (Lacan).

\section{KLÍčOVÁ SLOVA}

Román, film, adaptace, událost (Derrida), reálné (Lacan).

Román Cormaca McCartyho Cesta vyšel v roce 2006 jako desátá autorova kniha. V kritických ohlasech byla oceňována volba tématu, myšlenková mnohovrstevnatost, způsoby vyprávění, užití úsporných stylových prostředků, přímá inspirace Hemingwayovým psaním, intertextové odkazy na klasickou americkou literaturu 20. století i nová perspektiva, s níž zpřítomňuje obecné lidské 
problémy odkryté ve starší tvorbě (Suttree, Krvavý poledník). Recenzenti upozorňovali, jak v knize ožívají př́běhy a mýty amerického západu, paradoxy „jižanské gotiky“, témata opouštění domova či pesimistický pohled na člověka, jehož násilná povaha nakonec přivede lidstvo k záhubě (srov. WALSH 2008). Román byl v roce 2007 oceněn Pulitzerovou cenou. Do širšího povědomí ho dostaly jeho temné tóny, které dnešní americká kultura spojuje s kvalitou. Cormac McCarthy v době uvedení knihy svolil k několika rozhovorům, přičemž ten nejznámější se konal ve slavné televizní show Oprah Winfrey. Za tvưrčí impuls k napsání Cesty zde označil svoji lásku k malému synovi: „Hodně jsem myslel na svého chlapečka a v hlavě mi vyvstávaly obrazy hořících kopců a všeobjímající zkázy. Zájem čtenářů o knihu i úspěšný film bratrů Coenových No Country for Old Men (2007), jehož předlohou byl stejnojmenný McCarthyho román, přispěl k rychlému adaptování Cesty již v roce 2009. Recenzní ohlasy na filmovou verzi byly spíše rozporuplné: shodovaly se na tom, že pietní přistup režiséra Johna Hillcota a scenáristy Joa Penhalla byl málo odvážný, nebot nevyužili stylistických ani tematických podnětů románu a př́liš důsledně se drželi textu knihy (srov. PUIG 2014; srov. KELLY 2009).

Jedno ze základních témat Cormaca McCarthyho, bezvýznamnost lidské existence ve světě bez Boha (srov. CANT 2009: 185), je v Cestě rozvinuto v příběhu otce a syna, kteří putují spálenou zemí na jih, kde, jak otec doufá, mohou nalézt příznivější podmínky pro život. Ke katastrofě, jejíž příčina není zřetelně pojmenována, došlo před sedmi lety, tedy ještě před narozením chlapce: „Hodiny se zastavily na 1:17. Dlouhý záblesk a pak série nepatrných otřesů“ (McCARTHY 2008: 39). Svět, jak jej známe, přestal existovat, nebot’ se proměnil v tmavou, mrazivou pustinu. Naživu nezůstala žádná zvířata, ptáci, ryby, hmyz, vyhynuly stromy a rostliny. Mrtvé kmeny se řítí k zemi při zemětřeseních, nebo je pohlcují obrovské požáry. Přežilo jen nemnoho lidí ocitnuvších se v nehostinném prostředí. Zemi sužovanou nedostatkem slunečního svitu, mrazem a všudypřítomným popílkem nelze po vzoru starých osadníků začít opět dobývat, lidé mohou pro svoji obživu jen hledat to, co ještě nebylo nalezeno jinými přeživšími:

„Tou dobou už byly všechny obchody s potravinami prázdné a po kraji se vraždilo všude. Záhy už svět obývali převážně jen chlapi, co vám před očima snědí dítě, a města ovládly ušmudlané plenící bandy; lidé se hrabali v troskách a svítily jim jen zuby a oči, když pak ze sutin vylezli a v kusech nylonové sítě si nesli očouzené neoznačené konzervy - jako by nakupovali v pekelném krámu“ (McCARTHY 2008: 119). 
Otec a syn jsou štvanci vystavení neustálému strachu z ozbrojených gangů kanibalů, jejichž pronásledování, zotročování, znásilňování a zabíjení ostatních lidí ukazuje, k jakým koncům vede opuštění základních civilizačních pravidel. Obzvláště otec zvažující aktuální okolnosti si je vědomý všudypřítomného nebezpečí. Děsivost situace dokreslují nepohřbené pozůstatky lidí, kteří bud’ zemřeli při katastrofě, nebo spáchali sebevraždu. V intenzifikaci této hrůzy se vyjevuje temná stránka světa. Na povrch se dostávají negativní stránky lidské povahy tím, jak román ukazuje, čeho je schopen člověk vystavený extrémnímu strádání.

\section{Alegorické čtení}

Román Cesta je pojatý jako podobenství o bloudění světem. Základní mezilidská situace je vykreslena na obecné rovině - otec a syn nemají jména a jejich příběh by se tedy mohl odehrávat kdekoliv, byṫ v prostorovém rozvržení rozeznáváme americké reálie. ${ }^{1}$ Cesta je postapokalyptická próza evokující konec světa a sociálního pořádku v katastrofických vizích zmaru, zpustošení (srov. COLLINS 2014: 13) a oddělení většiny lidí od morálního vnímání. Filmová adaptace takové žánrové určení doplňuje, nebot při svém soustředění na „love story“ a dramatické situace spojené s extrémním tlakem na protagonisty účinně zapojuje do své formy další složky - thriller či western, a především konvence „romance“. Podle Northropa Frye je v romanci struktura příběhu podřízena náladě nebo myšlence a dochází k silné polarizaci postav a jejich jednání, což vede ke zřetelnému oddělení dobra a zla. Tomu odpovídá i překlopení postav na konstrukty, nositele typických vlastností, které vzdorují filozofickým otázkám a podporují alegorické čtení. Frye pak dále v romanci rozeznává dva světy:

„Prvně tu máme svět spojený se štěstím, bezpečím a mírem; důraz se často klade na dětství nebo na ,nevinnou' neboli pregenitální fázi mládí a výjevy zachycují jaro a léto, květiny a sluneční svit. Tento svět budu nazývat světem

1) Román lze číst i jako hyperbolizaci současné americké společnosti znejistěné projevy extremismu, teroristickými útoky z 11. září, válkami v Iráku a v Afganistánu, debatami o narušeném ekosystému a potenciálními hrozbami vyplývajícími z globálního oteplování. Obrací se tedy $\mathrm{k}$ současnosti a varuje před noční můrou zkázy, do níž se můžeme jednoho dne probudit (srov. WARNER 2006). Filmaři natáčeli v zónách zasažených katastrofami a devastací: „Vyrazili jsme do New Orleans, abychom natočili interiérové scény v obchodním centru, které zničil hurikán Katrina. Využili jsme povrchových dolů v západní Pensylvánii. Dokonce i mohutná oblaka v pozadí jisté scény pochází z 11. záríi. [...] nebylo obtížné taková místa najít. Americká krajina už je značně zpustošená“ (CHIARELLA 2009). Takové propojení reálného s fikčním přispělo $\mathrm{k}$ zesílení traumatických šoků vyplývajících z konkrétních, známých událostí. 

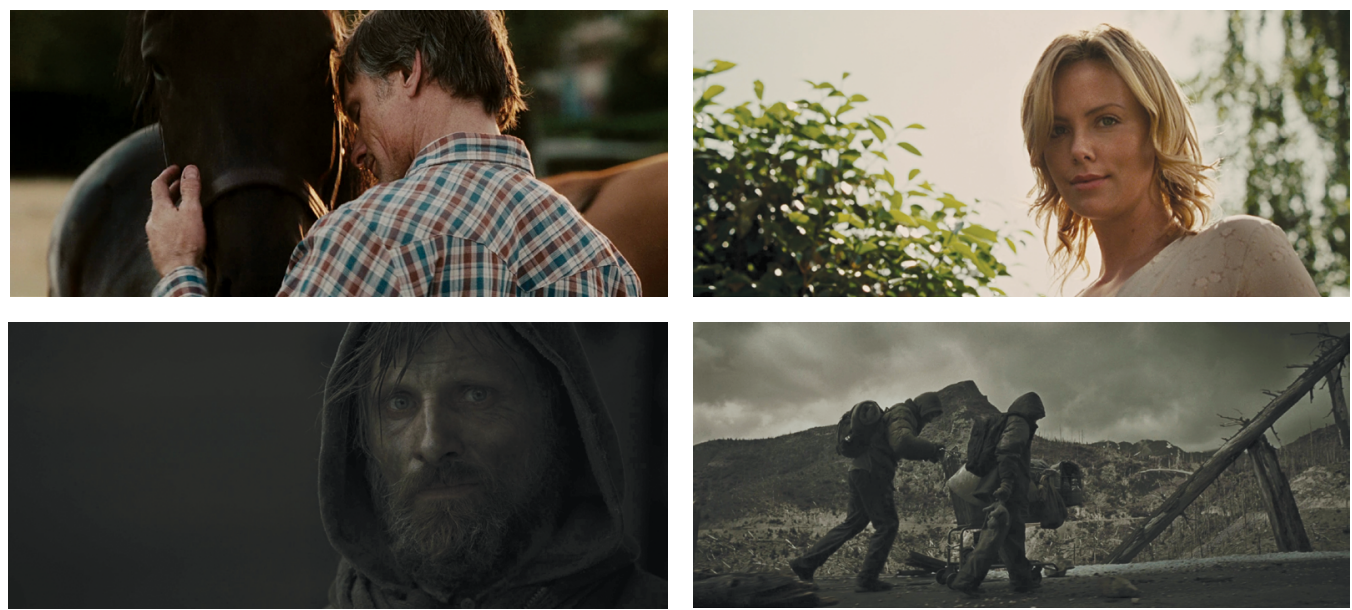

Svět před katastrofou a po ní je ve filmu vyjádřen vizuálními kontrasty

idylickým. Druhý svět tvoří vzrušující dobrodružství, avšak jsou to dobrodružství, která zahrnují odloučení, osamělost, ponížení, bolest a hrozbu ještě většího utrpení. Tento svět budu nazývat světem démonickým či nočním“ (FRYE 1976: 53).

Rajský stav je v románu i ve filmu vystřídán pádem, po němž následuje návrat do situace, která se alespoň blíží původnímu hodnotovému systému. Závěr přináší pozitivní rozuzlení, nebot' chlapec po smrti otce nachází rodinu zastávající etická pravidla, jež sám zdưrazňuje. Konec filmu je pak vystavěn na hollywoodském půdorysu: stř́idající se záběry na otce, matku, děti, a dokonce i psa, společně s působivými hudebními motivy jsou dokladem toho, jak film stimuluje emoce diváků: „Štastné konce obvykle uspokojí naši potřebu jednat a zbaví nás rozkolu vyvolaného negativní emocí, takže jsme pak spokojení a vyrovnaní" (BERLINER 2017: 146).

Svět před katastrofou a po ní je ve filmu vyjádřen vizuálními kontrasty. Flashbacky do rajské narativní minulosti jsou barevné a výrazně kontrastní, v montážích spatříme ženu a muže, okamžiky sblížení a radosti. Oproti tomu narativní přítomnost je oním „nočním světem“, čehož je dosaženo celkovou potemnělostí, monochromatickým provedením, malým kontrastem a velkými celky, v nichž se lidé stávají nepatrnými. Do vyprávění vstupujeme záběry na zelené stromy, barevné květiny, díváme se do tváře mladé ženy a posléze vidíme muže hladícího koně. Úvodní sekvence končí záběrem na dveře, v nichž se zavírá sítka proti hmyzu: barvy ještě zůstávají, ale rastr narušuje úvodní idylický 
pohled. Následuje noční scéna, kdy se muž a žena budí do katastrofy a muž začne jednat, aby ochránil svoji těhotnou manželku. Ostrým střihem se přenášíme do narativní přítomnosti, kdy se muž opět probudí, tentokrát vedle svého syna kdesi v pustině. Povahu světa po katastrofě odhalují následující bezútěšné záběry na rozbitou silnici, uschlé stromy, všudypřítomný popel. V potemnělých celcích nelze spatřit žádné barvy. „Každý den je více šedý než ten předchozí,“ slyšíme otcův unavený hlas mimo obraz, „a je stále chladněji, jak svět postupně umírá." Návraty do narativní minulosti se opakují, přičemž zintenzivňují kontrast s narativní současností.

Románový muž se dostává na vrchol beznaděje, kdy kolem sebe vidí jen temnotu a uniká mu smysl cesty. Homodiegetický vypravěč nám umožňuje sledovat události z jeho pohledu, zatímco nitro chlapce zůstává skryté. Poznáváme tak mužovy etické a teologické úvahy. Skepse se projevuje na rovině spirituální: „Zdvihl obličej ke světélkující obloze. Jsi tam? zašeptal. Spatřím tě v poslední chvíli? Máš vůbec krk, aby tě šlo uškrtit? Máš srdce? Bud’ navěky proklet... A máš vůbec duši? Ach bože, šeptal. Bože“ (McCARTHY 2008: 14). Tomuto heretickému výkřiku se sice filmaři vyhnuli, nalezli však jiný způsob, jak vyjádřit beznadějnost situace protagonistů $v$ brutálním světě. $V$ jedné $z$ epizod využili aluze na starozákonní text. Ve velkém celku vidíme zezadu muže a chlapce kráčející po cestě, nad níž se tyčí obrovský billboard. V následujícím záběru se kamera soustředí na slova dopsaná na něj: „Hle, údolí vraždění. Jeremiáš 19: 6“. Otcův hlas mimo obraz záhy poté hovoří o strachu z kanibalů. Biblická parafráze prorokových slov: „Proto hle, přicházejí dny, je výrok Hospodinův, kdy toto místo se už nebudou nazývat Tófet či Údolí syna Hinómova, nýbrž Údolí vraždění“ (Jr 19: 6). Následující verš (9) začíná slovesem „způsobím“ („Způsobím, že budou jíst maso svých synů a maso svých dcer, jeden bude požírat maso druhého v obležení a tísni, až je budou tísnit jejich nepřátelé a ti, kdo jim ukládají o život“, Jr 19: 9), čímž se projevuje vůle Hospodinova. Tomu by odpovídal
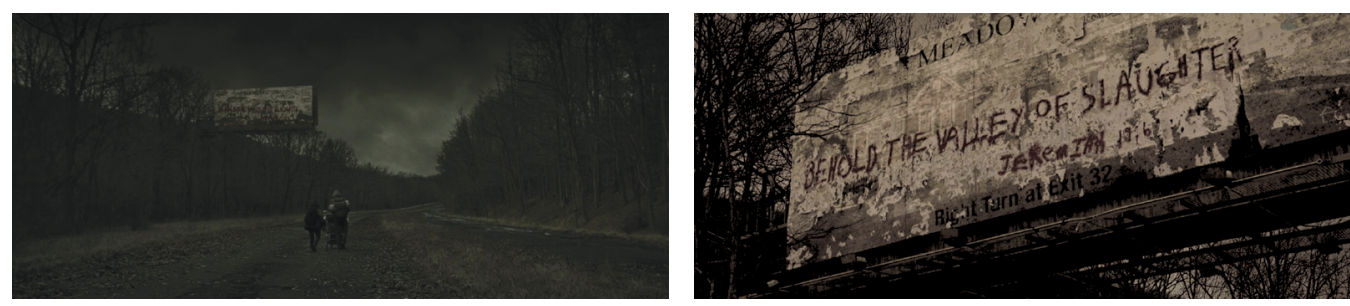

V jedné z epizod filmaři využili aluze na starozákonní text: „Hle, údolí vraždění. Jeremiáš 19: 6“ 
i pravděpodobný vnější zdroj apokalypsy - náraz meteoritu. ${ }^{2}$ Člověk se odvrátil od Hospodina, klaněl se Baalovi, což je možná paralela k „Molochu“ konzumu, nyní evokovanému rozvrzaným nákupním vozíkem. Krutost lidí předcházela trest, jehož forma ji poté ještě více zviditelní. Hinom se v dalším jazykovém vývoji stal Gehennou - výrazem pro peklo. Nastalá situace je natolik děsivá, že si nevystačíme s označením peklo a je třeba ji dokreslit spojením „údolí vraždění“.

Román i film se pohybuje na dvou úrovních. Na jednu stranu se lidé řídí instrumentální racionalitou, jednají neeticky, nebot jejich základní motivací je maximalizace výhod (např. kanibalové číhající u cesty). Na druhou stranu se i v tomto světě pohybují lidé, jejichž jednání je založeno na etice. Existence této, byt’ minoritní, skupiny naznačuje, že i v obecné beznaději pomalu roste víra $\mathrm{v}$ to, že navzdory troskám a brutalitě lze smysluplně existovat. V základní linii totiž vyprávění kupředu posouvá tematizace lásky otce $\mathrm{k}$ synovi (to knihu odlišuje od jiných apokalyptických románů i od starší tvorby McCarthyho). Všechny kroky, které otec podniká, dělá z lásky k synovi. Snaží se jej ochránit před smrtelným nebezpečím, jež oběma v každém okamžiku hrozí.

Muž a chlapec tlačící nákupní vozík mrazivými dny se pokouší udržet smysl pro pozitivní hodnoty, jakými jsou empatie či odpovědnost. Tyto motivace je odlišují od jiných přeživších, nebot společně „nesou oheň“. Pamětové stopy oživuje muž především vyprávěním příběhů, v nichž vítězí odvaha a spravedlnost. Navzdory všem útrapám i násilné lidské povaze se v některých lidech obnovuje cosi pozitivního, co lidský osud vyzdvihuje nad absurdní vyznění základních otázek existence. Otec a především syn, který je „svědomím“ románu i filmu, reprezentují život založený na etice. Naproti tomu krutí kanibalové jsou redukováni na biologii a jejich jednání je čistě funkční. Soudržnost a spolupráce nezaložená na biologickém faktoru vytváří i za této situace naději, že lidé jsou lepší, než by se mohlo zdát.

\section{Limity symbolického řádu}

Román i film Cesta odhalují - řečeno s Jacquesem Derridou - nekompatibilitu singularity aktuální události s jejím zprostředkovaným znakovým opakováním.

2) V románu ani ve filmu nelze vystopovat jednoznačnou př́ičinu katastrofy, nebot klíčové otázky spočívají na jiných těžištích. Jak uvádí sám autor: „Na to se mě ptá hodně lidí. Nezaujímám žádné stanovisko. V Institutu Santa Fe pracuji s vědci z nejrůznějších oborů a někteří geologové říkali, že podle nich to vypadá na meteorit. Ale mohlo by se jednat o cokoli - o sopečnou aktivitu nebo o jadernou válku. Př́liš na tom nezáleží. Hlavní ted’ je - co si počneš nyní?" (McCARTHY 2009) 
Má-li být událost skutečnou Událostí - tím, co nelze očekávat, co rozvrací veškerý náš život -, potom jsme zároveň konfrontováni s nemožností její možnosti (DERRIDA 2007: 461). V Cestě na sebe Událost bere zřejmě narativní podobu pádu meteoritu, a není náhodou, že se jak film, tak román vypořádávají až se samotnými traumatizujícími, ničivými důsledky tohoto vpádu Události do všedního života. Událost je trauma v celé šiři tohoto pojmu: fyzické trauma na sebe bere podobu zničeného životního prostředí, zničeného života na Zemi - z něj pak dále rezultují psychická traumata postav. Jak už jsme naznačili, samotný okamžik katastrofy není zachycen - snad proto, že by to znamenalo, že s Událostí se už počítalo, že byla očekávaná, že tedy byla jen událostí. Muž se probouzí

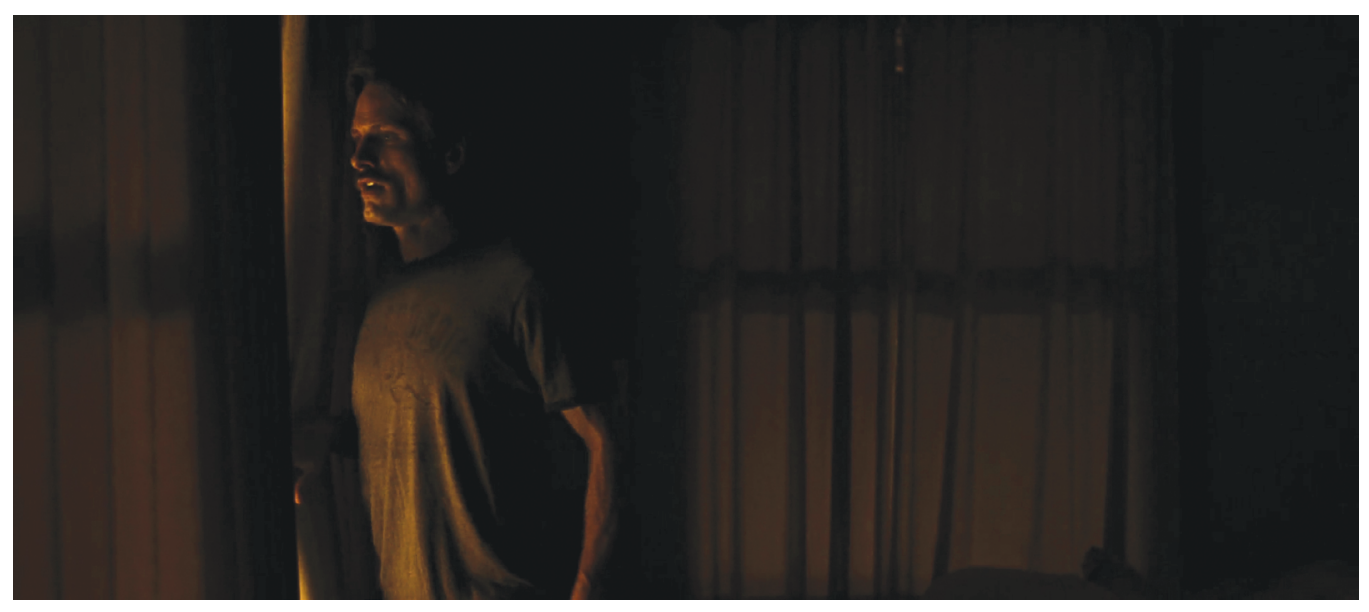

Román ani film zachycovat samotnou Událost nemůže - ta je nereprezentovatelná. Jakýkoli popis (i pouhý pohled kamery) by totiž singularitu Události devalvoval 
uprostřed noci a za oknem spatří obrovské ohně. Začne konat a napouští vanu vodou. Záhy se probouzí těhotná manželka a ptá se, zda se jde koupat. Přichází jen záporná odpověd’, nic víc. Kamera se soustředí již jen na vyděšený výraz ženy osvětlovanou ohněm, ve zvukové stopě slyšíme výkřiky lidí. Román ani film zachycovat samotnou Událost nemůže - ta je nereprezentovatelná. Jakýkoli popis (i pouhý pohled kamery) by totiž singularitu Události devalvoval.

To, co bylo, to, co přeživší bezpochyby vnímají jako skutečnost, již neexistuje, a na druhou stranu je v románu i filmu evokován krutě skutečný svět, jenž je zároveň právě pro svou bezprostřední krutost a vyprázdněnost, pro svou nekompatibilitu s minulou podobou světa „neskutečný.“ Mezi světem před katastrofou a po ní vlastně není žádná kontinuita, jen náznaky čehosi předchozího v podobě nesmyslných trosek a vzpomínek, které jsou neseny nespolehlivou lidskou pamětí, troskami měst a lidských obydlí, mrtvými kmeny stromů. To vše jsou „přízraky minulého světa“, který už funguje právě jen jako přízrak, který zabraňuje některým postavám přijmout novou podobu světa plně za svou. Člověk není schopen se zcela vyrovnat s neočekávaným zborcením všech etických, sociálních systémů, s rozpadem širokého spektra služeb. Jacques Lacan ve své revizi Freudovy psychoanalýzy přináší pojem Reálného. To by mělo být oním před-jazykovým obdobím dětství, kdy člověka zajímají jen základní potřeby a je „přímo“ (ve smyslu materiálním) napojen na vnější svět. Reálné je před-diskursivním, fyzickým, surovým základem lidského bytí. Tento stav končí, jakmile začneme užívat jazyka, nebot’ se odcizujeme přírodě tím, že vše podřizujeme signifikaci - symbolickým a obrazovým vzorcům. Pro člověka v dnešní fázi evoluce není konfrontace s reálnem možná bez opory jazykového, symbolického systému (a proto se s ním nelze vlastně potkat - snad jen na nevědomé úrovni, kam jej symbolizace vytlačuje). Přesto se nabízí svůdná domněnka, zda snad člověk nemůže být konfrontován s Reálným alespoň na chvíli právě v důsledku Události, která veškerou oporu symbolického systému svým traumatizujícím dopadem rozrušuje a zneplatňuje.

Lacanovské Reálno je pouští, absencí významu i smyslu, oblastí ukájení primárních potřeb. Stejně tak pustý, vyprázdněný, nezhojitelně traumatizovaný je i filmový svět. $V$ jistém smyslu můžeme říci i to, že Reálné bylo v minulé verzi světa přítomno latentně (nevědomě - v podobě nočních můr), představovalo základní, byt’ netematizovatelnou součást života. A možná je aktuální podoba světa aktualizací oné latence, jak naznačuje postava starce Elyho, který hovoří o znameních předcházejících U/událost. Noční můry se staly běžnými jevy, ptáci, květiny, zeleň nejsou, „skutečnost“ je v porovnání s minulou podobou 
světa traumatickým „fantazmatem“ (LACAN 1988). Skutečnost minulého světa již nemá žádnou oporu v nové situaci, překlopila se do úrovně snění či bájných přiběhů o létajících ptácích, do lacanovského Imaginárna.

Otec se nadále pokouší přemostit oba světy tím, že svému synovi odkrývá (popisuje, rekonstruuje) předměty a jevy minulého světa. Mnohé $z$ toho, o čem hovoří, si dokáže chlapec jen obtížně představit (kupříkladu chlapec nereaguje na poznámku „jako když letí vrána“, protože nikdy neviděl letět ptáka). Otevírá se tím otázka sdělitelnosti něčeho, co neexistuje. Vyprávěním příběhů umožňuje otec synovi projektovat se do toho, co nezažil, tedy participovat na něm alespoň prostřednictvím již zmíněné sféry Imaginárna. $\mathrm{M}$. Bachtin ve studii Autor a hrdina v estetické činnosti uvažuje nad tím, jak v umění poznáváme sami sebe, což by ovšem nešlo bez naší schopnosti zažít různé situace prostřednictvím někoho jiného: „V živote pozeráme na seba očami druhého a vždy znovu sa vraciame do seba: posledná, akoby rezumujúca udalost’ sa v nás uskutočňuje v kategoriách samého života" (BACHTIN 1988: 26). Máme mimořádnou kapacitu projektovat, získávat informace, které bychom o sobě jinak neměli. $Z$ těchto projekcí se nakonec dokážeme i poučit. $V$ tomto ohledu je román i film naplněn nejen pokusy popsat to, co už není, starými příběhy o pozitivních lidských vlastnostech, ale i řadou instruktivních situací gradujících s tím, jak otci docházejí síly a pokouší se chlapci předat své zkušenosti. Z nich pak plyne, jak by se měl chlapec chovat za těch či oněch okolností. Ve chvíli takových sdělování je chlapec mimo situaci, která na něj teprve čeká (setkání s mužem-zachráncem záhy po otcově smrti) a při předávání by jej jen limitovala. Teprve vystoupení ze situací nám přináší obohacení. Konstituované „já“ chlapce je vtěleno do románu a jeho adaptace.

Intenzivně pocitované ztráty ještě více podtrhují to, co je ztracené. Objektem otcovy touhy je starý svět (a to pravým objektem touhy, nebot tento svět je nedostupný). Živá příroda se otci zjevuje ve snech přenášejících jej do minulé podoby světa, který se stal právě již jen fantasmatem, nebot do něj není možné vstupovat jinak než právě jen prostřednictvím snů. Na samotném začátku vyprávění se otec nostalgicky vrací do narativní minulosti, do časů, kdy byl sám ještě chlapcem. V záblesku vzpomínky vidíme, jak se svým strýcem vyjíždějí na jezero a zažívá jeden z nejkrásnějších dnů. Návrat je evokován vizuálními postupy. Chlapcovýma očima spatřujeme veslujícího strýce s fajfkou a slamákem, okolní krajinu odhalovanou ve velkých celcích: „Na břehu rostly břízy - jako kosti se rýsovaly na tmavozelených jehličnanech za nimi“ (McCARTHY 2008: 15) - i detailech: „V průzračné vodě mrtvý okoun břichem nahoru. Žluté listí“ 
(McCARTHY 2008: 15). Text dále evokuje atmosféru krásného dne jeho dětství dalšími smyslovými prožitky, které prohlubují plastičnost zážitku: „seděl na zádi člunu ruku měl ponořenou ve studené zčeřené vodě [...]“, „jen pravidelné cvakání a šoupání veslových vidlic“ (McCARTHY 2008: 15).

Jiná mužova vzpomínka z období krátce po katastrofě se soustředuje na chování ptáků: „[...] obletovali zemi právě tak tupě, jako když na kraj misky sedají mouchy“ (McCARTHY 2008: 40). Endogenní příčiny migračního jednání ptáků přetrvaly katastrofu, nebot’ jsou nadále fixovány v jejich DNA, ale sám let je marný. Vnější důvody pominuly: už nemohou nalézt kvalitnější biotopy, nedochází ke změnám ročních dob, teplot a srážek. Základní principy života na zemi (alespoň podle tvrzení evolučních biologů, kteří zasazují původ migrace až k nejstarším organismům, srov. BOWLIN: 2010) pozbyly na významu. Životní prostředí se změnilo a již nejsou důvody pro překonávání vzdáleností a bariér. Malý chlapec již ptáky - a tedy potažmo i základní evoluční principy nemohl poznat a setkává se jen s jejich podobou v knížkách, v nichž jsou uměle udržováni jako připomínka toho, co už není. Jak dlouho toto udržování bude fungovat? Románová výpověd je skeptická: „Svět se scvrkával kolem samého jádra analyzovatelných jednotlivostí. Názvy věcí ony věci pomalu následovaly do zapomnění. Barvy. Jména ptákü“ (McCARTHY 2008: 61). S tím, jak přestali existovat, se pomalu vytrácejí i jasnější představy o nich (jeden z hrdlořezů má na krku „vytetovaného ptáka, ale umělec sotva tušil, jak pták vypadá“).

Poslední odstavec románu se vrací $\mathrm{k}$ tomuto tématu:

„Kdysi bývali v horských bystřinách siveni. Byli vidět, jak stojí v jantarovém proudu, bílé okraje ploutviček se míhaly ve vodě. V ruce byli siveni cítit mechem. Kroutili se, lesklí a svalnatí. Na hřbetě měli klikatou kresbu, mapu světa ve svém prvopočátku. Mapy a bludiště. Mapy toho, co už nelze vrátit. To už se nedá napravit. V hlubokých roklích, kde žili, bylo vše starší než člověk, všechno si broukalo a bzučelo nad tou nekonečnou záhadou“ (McCARTHY 2008: 185).

Pasáž, která nemá zřetelnou souvislost s předchozím vyprávěním, se stala předmětem řady otázek a diskuzí. John Cant v ní spatřuje připomenutí, že jednoho dne „[...] všechny věci pominou a vzorec pohybu, který se v pradávných dobách uvedl v chod, jednou ustane a dny už nebudou, nebot’ nezbude nikdo, kdo by měřil, jak ubíhaji“ (CANT 2009: 197). Lee McCarthy zase píše o obnovování vzpomínek na ztracený svět, jakkoliv nevíme, kdo je oním zdrojem paměti: „[...] stejně jako chlapcova záchrana představuje ona pamět náznak spásy na konci trýznivé cesty“ (HAGE 2010: 104). Andrew Keller Estes ji vykládá jako 
biocentrickou mapu, která nás nabádá k lepší interakci se životním prostředím (ESTES 2013: 213). A tak bychom mohli pokračovat.

Pro nás je ovšem stěžejní, že ono „tajemství přírodního dění nás navrací k Reálnému, jeho samostatné existenci nezávislé na diskursivní konstrukci otce nebo jeho syna. Příroda je v thoreauovském smyslu suverénní, lidé pro ni nejsou důležití. Závěr je aporetický, připomíná zenový koán: jak je možné popisovat přírodu, v níž není nikoho, kdo by ji popsal? Na Lacanovu otázku „Říká se, že člověk je měřítkem veškerých/všech věcí. Co však poměřuje jeho? Nalezneme to v něm samém“" (LACAN 1988: 68), nicméně nabízí odpověd”: člověka zřejmě třeba není.

\section{Závěr}

Ukázali jsme, že román na jednu stranu redukoval člověka na jeho biologickou podstatu, na druhou zase poukazoval na přežití rudimentárního, etického vědomí i za podmínek extrémního tlaku na jedince. Autoři filmové adaptace pak rozehráli žánr romance, aby tento význam ještě více posílili. Závěr filmu ukazuje, jak hrdinův pád do post-apokalyptické hrůzy vyvrcholí nalezením své skutečné lidské podstaty.

McCarthyho je však také možné chápat jako postmoderního autora vedoucího spor s racionalitou modernismu. Proti instrumentálnímu, rozumnému jednání (být kanibalem znamená přežít) staví nesmyslnost etického jednání. Takové jednání je nerozumné v tom, že znevýhodňuje ty, kteří se eticko-morálními principy řídí. Otázkou zůstává, proč se jako všechny trosky minulého symbolického systému tento božský, etický princip také neproměnil do pouhé podoby fantasmatu.

Protože jím vždy byl? Protože touha po transcendenci smyslu je opět touhou v tom pravém smyslu toho slova: realizovanou jen aktem víry, ale nikdy nedosažitelnou? Nebo je důvod jiný? Na otázku, jak to, že tento transcendentní symbolismus s sebou Událost také nevzala, potom můžeme spekulativně odpovědět, že snad nějakým způsobem přináleží $\mathrm{k}$ Reálnému jako jeho doplněk? Je snad projekcí Reálna, která prostřednictvím náboženského symbolismu „sni“" o Reálném jako o tom, co předchází všechny věci, mluvím samozřejmě o té podobě, v níž nás náboženství informuje o „rajské“ verzi světa, která je snem o „Reálném“ proto, nebot sní o nedostupném a tudíž traumatizujícím světě; o světě před jazykem, před poznáním, před Událostí - před Pádem. Symbolično sní o Reálném; Reálné v sobě obsahuje sen o totálním symbolu. Už se nejedná o na- 
vzájem se nahrazující, vytěsňující režimy, oba jsou na sobě závislé, oba obsahují svůj protipól coby předmět touhy. Kruh. Nebo koán.

\section{PRAMENY}

McCARTHY, Cormac

2008 Cesta, přel. Jiří Hrubý (Praha: Argo)

\section{LITERATURA}

BACHTIN, Michail 1988 Estetika slovesnej tvorby, přel. Viera Šabíková (Bratislava: Tatran)

Bible: Písmo svaté StaréHo a NovéHo zÁKONA 1993 (Praha: Česká biblická společnost)

BOWLIN, M. S. et al. 2010 "Grand challenges in migration biology“, in Integrative and Comparative Biology (McLean VA: Society for Integrative and Comparative Biology), s. 261-279

BERLINER, Todd

2017 Hollywood Aesthetic (New York: Oxford University Press)

CANT, John

2009 „The Road“, in Harold Bloom (ed.) Cormac McCarthy (Langhorne: Chelsea House Publications), s. $183-200$

COLLINS, John 2014 The Oxford Handbook of Apocalyptic Literature (Oxford: Oxford University Press)

DERRIDA, Jacques 2007 „A Certain Impossible Possibility of Saying the Event“, Critical Inquiry Vol. 33, No. 2, s. 441-461

ESTES, Andrew Keller

2013 Cormac McCarthy and the Writing of American Spaces (Amsterdam: Rodopi)

FRYE, Northrop

1976 The Secular Scripture (Cambridge, Mass: Harvard University Press)

HAGE, Eric 2010 Cormac McCarthy: A Literary Companion (North Carolina: Jefferson) 
Petr Bubeníček

Alegorické a reálné v románu a filmu Cesta

\section{CHIARELLA, Tom}

2009 „'The Road” Is the Most Important Movie of the Year“, Esquire; dostupné z: https://www.esquire.com/ entertainment/movies/a5878/the-road-movie-review-0609/, přístup 2. 4.2014

\section{KELLY, Christopher}

2009 „Apocalypse Now“, texasmonthly.com; dostupné z: https://www.texasmonthly.com/articles/apocalypse-now/, přístup 27. 3. 2018

\section{LACAN, Jacques} 1988 The Seminar of Jacques Lacan Book II: The Ego in Freud's Theory and in the Technique of Psychoanalysis 1954-1955, Jacques-Alain Miller (ed.), přel. Sylvana Tomaselli (New York: W.W. Norton)

McCARTHY, Cormac

2009 „Hollywood's Favorite Cowboy“, The Wall Street Journal, dostupné z: https:/www.wsj.com/articles/ SB10001424052748704576204574529703577274572, př́stup 3. 4. 2018

\section{O’DONNELL, Patrick}

2010 The American Novel Now: Reading Contemporary American Fiction Since 1980 (Oxford: Wiley-Blackwell )

PUIG, Claudia

2014 „Child of God': Pray you don't have to see it“, USA Today; dostupné z: https://www.usatoday.com/ story/life/movies/2014/07/31/child-of-god-review/12787351/, přístup 1. 4. 2018

\section{WALSH, Chris}

2008 „The Post-Southern Sense of Place in 'The Road'“, in The Cormac McCarthy Journal, Vol. 6 (Penn State University Press), s. 48-54

\section{WILHELM, Randall S.}

2008 „Golden chalice, good to house a god: Still Life in 'The Road'“, in The Cormac McCarthy Journal, Vol. 6 (Penn State University Press), s. 129-146

\section{WARNER, Alan}

2006 „The road to hell“, The Guardian; dostupné z: https://www.theguardian.com/books/2006/nov/04/ featuresreviews.guardianreview4, př́stup 4. 4. 2018

\section{Mgr. Petr Bubeníček, Ph.D., petrb@phil.muni.cz. Ústav české literatury a knihovnic- tví, Filozofická fakulta Masarykovy univerzity, Brno, Česká republika / Department of Czech Literature and Studies, Faculty of Arts, Masaryk University, Brno, Czech republic}

